\title{
ENVIRONMENTAL THERMAL COMFORT OF A REDUCED MODEL USING CROSS-LAMINATED TIMBER
}

\author{
Carlos A. de P. Sampaio ${ }^{1 *}$, Rodrigo F. Terezo ${ }^{1}$, Guilherme Motta ${ }^{1}$, \\ Leonardo M. da C. Silva ${ }^{1}$, Ilson Vassem Júnior ${ }^{1}$
}

\begin{abstract}
${ }^{1 *}$ Corresponding author. Universidade do Estado de Santa Catarina - CAV/ UDESC/ Lages - SC. Brasil. E-mail: carlos.sampaio@udesc.br | ORCID ID: https://orcid.org/0000-0003-3931-3840
\end{abstract}

\section{KEYWORDS}

precasting in wood, self-supporting, thermal comfort, environmental factors.

\begin{abstract}
The challenges for the use of the cross-laminated timber (CLT) system in the Brazilian agricultural market are significant. This study evaluated the thermal performance of fiber cement tiles associated with a CLT non-conventional structure compared to those of ceramic, fiber cement and aluminum roof tiles based on following thermal comfort indexes (i.e., black globe humidity index (BGHI), radiant heat load (RHL) and specific enthalpy) using physical conventional models of reduced-scale rural facilities under summer conditions. The non-conventional CLT model comprised closing walls and a lining that form a self-supporting structure with few air inlets. This model presented reduced thermal comfort indexes compared to the other conventional roofs. Moreover, the CLT model has an average black globe temperature ( $\mathrm{Tbg}$ ) of $32.9^{\circ} \mathrm{C}$, which was lower at all times compared to those of the other roofs. In conclusion, the roof with fiber cement tiles associated with the CLT structure exhibited the best performance in terms of thermal comfort, followed by the ceramic, fiber cement, and aluminum tiles. The study results allow a better understanding of the opportunities for CLT usage.
\end{abstract}

\section{INTRODUCTION}

Thermal sensation (i.e., cold or hot) depends on the building material properties, including its surface temperatures and the facility of heat exchange with the medium. When exposed to solar radiation and other sources from the outside, tiles and walls cause hot environments internally, which consequently produces thermal discomfort. Traditional roofing materials are already relatively well known in buildings and are commercially available. However, new and unconventional materials must be evaluated to assess their thermal performance in agricultural facilities.

A constructive technology, called cross-laminated timber (CLT) or cross-cut laminated wood, has begun attracting interest in Brazil because of its industrialization and sustainable characteristics, also considering the country's great lumber potential.

Adekunle \& Nikolopoulou (2018), Leiva et al. (2018), and Kollár \& Štefko (2016) evaluated buildings using the CLT technique, aiming at thermal comfort in urban environments occupied by people; they obtained satisfactory results. However, studies on the use of this technology in agricultural facilities are scarce.
Among the evaluations performed for conventional and non-conventional roofing materials, the use of reduced models of rural facilities has been cited in the studies of Souza et al. (2018), Castro et al. (2017), Farias et al. (2017), and Silva et al. (2015, a, b).

Castro et al. (2017), Dalcin et al. (2016), Pérez et al. (2015), Marchezan et al. (2014), Neto \& Nääs (2014), Rosselle et al. (2014), and Melo et al. (2013) evaluated the thermal comfort of an environment using the black globe humidity index (BGHI $=T_{b g}+0.36 . T_{d p}+41.5$, in which $T_{b g}$ and $T_{d p}$ denote the black globe and the dew point temperatures $\left({ }^{\circ} \mathrm{C}\right)$, respectively) and the radiation heat load index $\left(\mathrm{RHL}=\sigma . \mathrm{MRT}^{4} ; \mathrm{MRT}=100\right.$. $\sqrt[4]{2,51 \sqrt{\mathcal{v}}\left(T_{b g}-T_{d b}\right)+\left(\frac{T b g}{100}\right)^{4}}$, in which $\sigma$ is $5.67 \times 10^{-8} \mathrm{~W} \cdot \mathrm{m}^{-2} \cdot \mathrm{K}^{-1}$ (Stefan-Boltzmann constant); $v$ = air velocity $\left(\mathrm{m} . \mathrm{s}^{-1}\right)$; and $T_{d b}, T_{b g}=$ dry bulb, black globe temperatures (K), respectively). Enthalpy, variables of moist air $(\mathrm{h})$, and black globe temperature $\left(T_{b g}\right)$ are also accepted as effective indices for evaluating building materials and the thermal comfort in environments considered in animal and plant production.

\footnotetext{
${ }^{1}$ Universidade do Estado de Santa Catarina - CAV/ UDESC/ Lages - SC. Brasil.
} 
In this context, this study aims to evaluate the thermal performance of a fiber cement roof associated with the CLT structure compared to those of clay, fiber cement, and aluminum roof tiles in reduced models of rural facility based on the thermal comfort indexes of BGHI, RHL, and effectiveness under the conditions of the summer season temperature.

\section{MATERIAL AND METHODS}

This study was conducted in the experimental area of Construction and Ambience in the Center of Agroveterinary Sciences of the Santa Catarina State University - Lages campus (Santa Catarina, Brazil), which has geographical coordinates of $27^{\circ} 49^{\prime}$ latitude south and $50^{\circ} 20^{\prime}$ longitude east, an average altitude of $940 \mathrm{~m}$, and a $\mathrm{Cfb}$ type of climate (i.e., mesothermic humid or temperate according to the Köppen Climate Classification System). Normally, the area does not have a well-defined dry season, with January as the warmest month (average annual temperature: $24{ }^{\circ} \mathrm{C}$ ). Present rain mainly comes in the summer season. Moderate winds prevail in the northeast direction.

Four models, which were constructed in a distorted reduced scale according to the similitude theory, were used
(Sampaio et al., 2018; Jentzsch et al., 2013) on 1:10 and $1: 2$ scales in the horizontal and vertical dimensions, respectively, with internal measures of $3.00 \mathrm{~m}$ length, 1.40 $\mathrm{m}$ width, and $1.50 \mathrm{~m}$ ceiling height.

Aside from allowing the testing of different construction configurations, using the reduced physical models based on the similitude theory to evaluate different roofing materials has other advantages, including low costs of materials and labor (Akamine \& Passini, 2017).

The models were based on the usual dimensions of poultry sheds (i.e., east-west direction and built away from each other to avoid shadowing). The lateral models (northsouth direction) were closed with two layers of transparent plastic to greenhouse formed by a $100 \mu \mathrm{m}$ film. Other possible openings, which were mainly in the roof, were closed with polyurethane foam to avoid maximum thermal exchanges by the wind. The surroundings were formed by thin grass and gravel.

A three-model structure was formed by bricks covered with mortar, concrete floor, and two-story roof of a wood structure. The fourth model was formed using the CLT system. Figure 1 displays all the models used in this study.
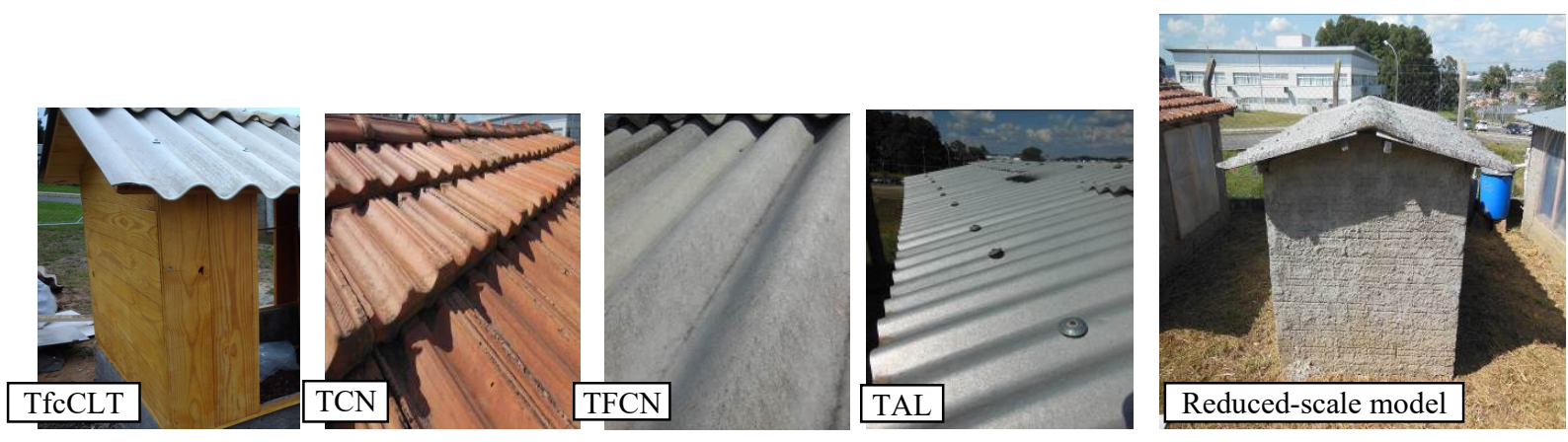

TfcCLT - corrugated fiber cement tiles mounted on the structural lining of the CLT formed by a self-supporting structure; TCN - ceramic tiles; TFCN - corrugated fiber cement tiles; and TAL - corrugated aluminum tiles.

FIGURE 1. External view of the evaluated roofs and the rural facilities reduced to model scale.

The CLT comprised three boards with $2.0 \mathrm{~cm}$ thickness each, which were crossed and glued with reactive polyurethane and sewn in the desired size to form a self-supporting structure of $6.0 \mathrm{~cm}$ thickness (Figure 2). Note that this is the first study that used CLT plates in agricultural construction and so the CLT plates had three layers, which is the minimum number required by the production technique for the plates to be compatible with the mechanical resistance necessary for distorted-scale constructions.

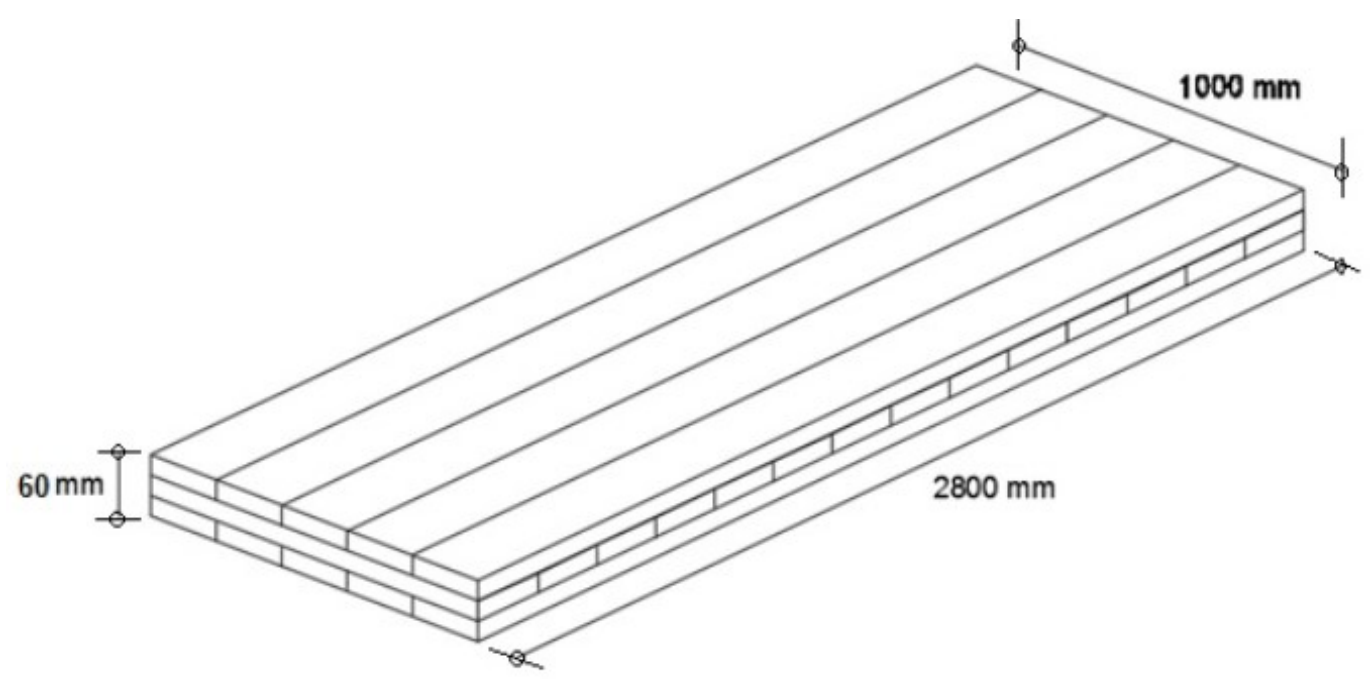

FIGURE 2. Manufactured cross-laminated timber scheme. 
The roofs evaluated herein were corrugated fiber cement tiles (TfcCLT: $5.0 \mathrm{~mm}$ thick; $k \cong 0.65 \mathrm{~W} / \mathrm{m} . \mathrm{K} ; \varepsilon=$ $0.95)$ mounted on the structural lining of the CLT $(6.0 \mathrm{~cm}$ thick; $k \cong 0.13 \mathrm{~W} / \mathrm{m} . \mathrm{K} ; \varepsilon \cong 0.80)$, formed by a selfsupporting structure, ceramic tiles (TCN: $k \cong 0.93 \mathrm{~W} / \mathrm{m} . \mathrm{K}$; $\varepsilon=0.95$ ), corrugated fiber cement tiles (TFCN: $5.0 \mathrm{~mm}$ thick; $k \cong 0.65 \mathrm{~W} / \mathrm{m} . \mathrm{K} ; \varepsilon=0.95)$, and corrugated aluminum tiles (TAL: $0.5 \mathrm{~mm}$ thick; $k \cong 205 \mathrm{~W} / \mathrm{m} . \mathrm{K} ; \varepsilon=$ $0.04) . k$ and $\varepsilon$ denote thermal conductivity and emissivity, respectively. The roof structure was built using timber with an average inclination of $25 \%$ of tiles.

The external air velocities were obtained by a portable digital thermo-anemometer (Model Itan-720), which presented an air velocity scale between 0.4 and 45.0 $\mathrm{m} . \mathrm{s}^{-1}$, accuracy of $\pm 3 \%$ reading $+0.2 \mathrm{~m} . \mathrm{s}^{-1}$, and resolution of $0.1 \mathrm{~m} . \mathrm{s}^{-1}$. The variations of the temperature and the humidity of the air and the black globe temperature $\left(T_{b g}\right)$ inside and outside the models were obtained with a digital black globe thermometer (Model ITWTG 2000/Instrutemp). The globe of this instrument was formed by a hollow brass sphere with $75.0 \mathrm{~mm}$ diameter. The wet bulb temperature (Twb) was obtained with a sling psychrometer (rotating handle).

The instruments were placed in the geometric center of each reduced-scale model (Castro al., 2017, Silva et al., 2015b) at $0.75 \mathrm{~m}$ floor height, as well as in the external environment. This height was chosen because it showed the geometric center of the model, thereby determining a comparison by higher heat (Figure 3).

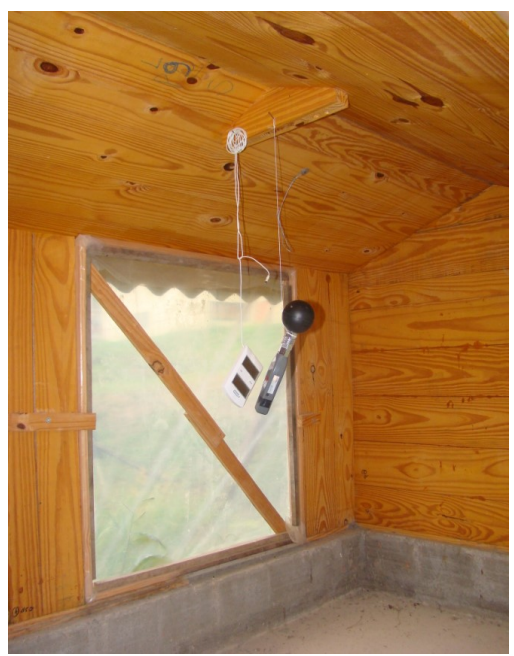

FIGURE 3. Position of the apparatus system used to obtain the experimental information.

The measurements were performed in 13 typical days during the summer season. The data were collected in January (10 days) and February (3 days) of 2019 based on the higher specific enthalpy values obtained at hourly intervals between 9:30 a.m. and 5:30 p.m. The days chosen for comparison had few or no incidence of clouds and rains and corresponded to the days of maximum heat. The BGHI, RHL, and $T_{b g}$ indices were used to evaluate the thermal environments. The external enthalpy of the air $(\mathrm{H})$ (Silva et al., 2015b) was calculated to determine the days with the highest "caloric content," which were considered as the days of greatest discomfort.

The BGHI, $\varepsilon=$ BGHI (environment) - BGHI (type of tile)/BGHI (environment) - BGHI (aluminum tile) formula was used to calculate the effectiveness $(\varepsilon)$ of each type of tile in relation to the aluminum tile. This index was used by Silva et al. $(2015, \mathrm{a}, \mathrm{b})$ to compare the roof tiles and the thermal comfort.

Randomized block design (daily hours), days as a repetition, and four treatments (roof type) were used to compare the thermal comfort indices. A no-shade external environment was used as the control. The data obtained were used for the analysis performed by means of the Ftest of the analysis of variance and Tukey's test at 5\% significance.

\section{RESULTS AND DISCUSSION}

Figure 4 illustrates the development of the BGHI index for the measurement schedules. 


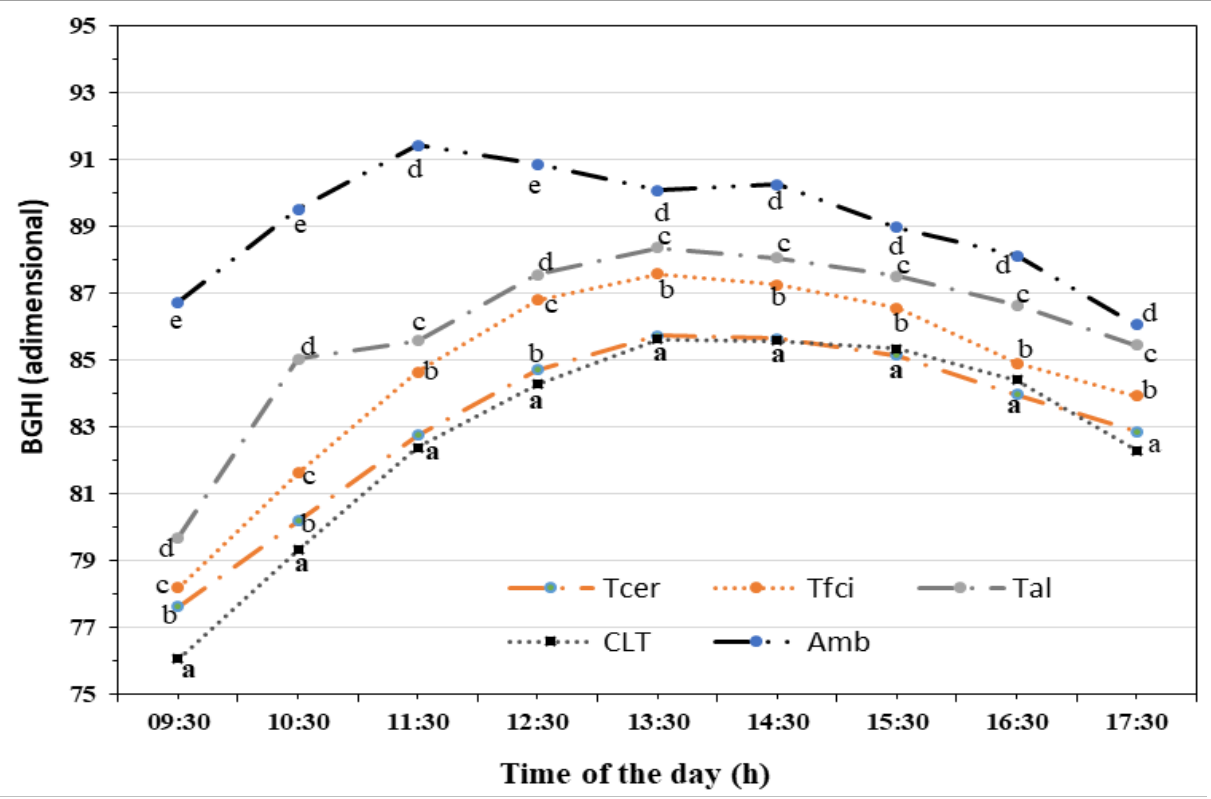

TfCCLT — corrugated fiber cement tiles mounted on the structural lining of the CLT formed by a self-supporting structure; TCN — ceramic tiles; TFCN - corrugated fiber cement tiles; and TAL - corrugated aluminum tiles. The means followed by different letters in the schedules indicate the statistical difference $(\mathrm{P}<0.05)$ for each time by Tukey's test.

FIGURE 4. Average values of the BGHI index for all treatments at different measurement times.

The average values of the BGHI (i.e., 82.80, 83.17, 84.61, and 85.98) were registered for the TfCCLT, TCN, TFCN, and TAL treatments, respectively. The TfcCLT and TCN treatments were statistically equal between 11:30 am and 05:30 pm. The aluminum tile exhibited a lower BGHI value than that of the fiber cement tile. The BGHI registered in the external environment (i.e., no-shade environment) was 89.20 , indicating the importance of roofing for thermal comfort. These results, in whole or in part, present a tendency and/or values similar to those obtained by Silva et al. (2015, a, b), Carneiro et al. (2015), and Akamine \& Passini (2017) for conventional roofs.
Considering $\mathrm{BGHI}=75$ as the limit value for the environmental thermal comfort of most animals cited in several studies, the tiles roofs presented a low thermal performance in hotter schedules.

Castro al. (2017) used polypropylene linings on fiber cement and ceramic roofs and concluded that this technique contributed to the reduction of thermal discomfort in environments, regardless of the tile type. This was similar to the result found in the present study using the CLT lining.

Figure 5 shows the development of the RHL index as a function of the schedules.

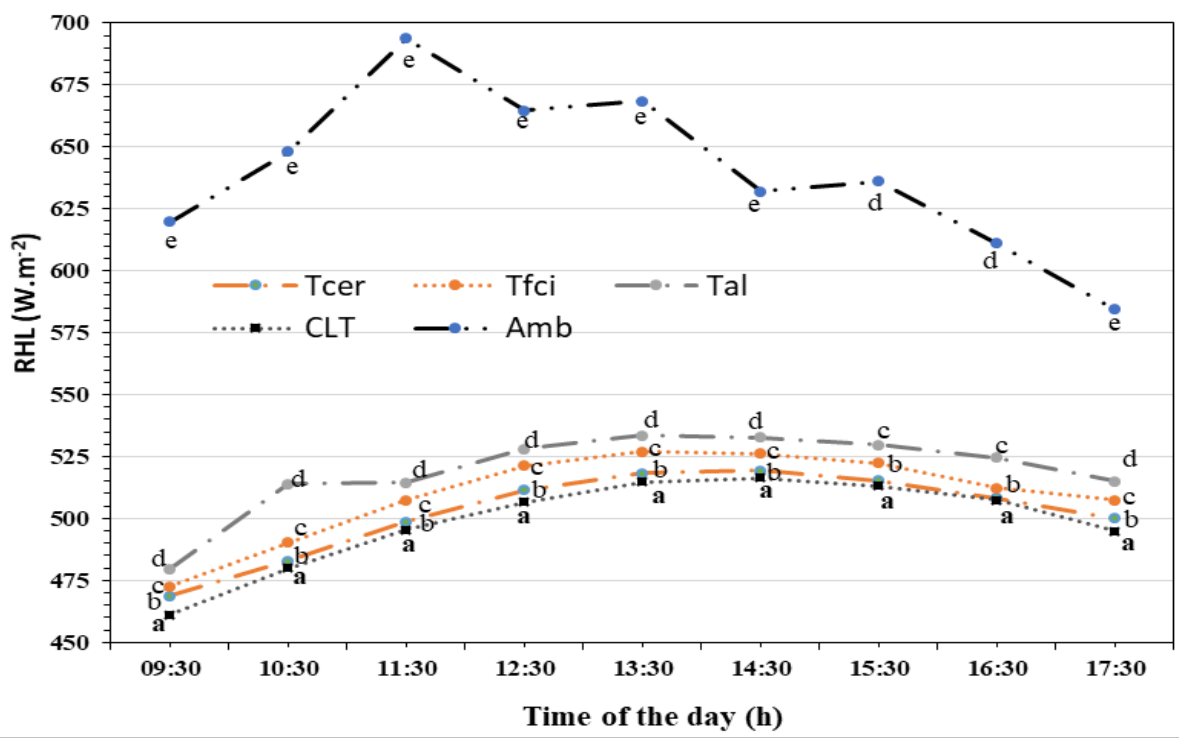

TfcCLT — corrugated fiber cement tiles mounted on the structural lining of the CLT formed by a self-supporting structure; TCN — ceramic tiles; TFCN — corrugated fiber cement tiles; and TAL — corrugated aluminum tiles. The means followed by different letters in the schedules indicate the statistical difference $(\mathrm{P}<0.05)$ for each time by Tukey's test.

FIGURE 5. Average values of the RHL index for all treatments at different measurement times. 
The average values of the RHL were of 498.87 , $502.59,509.63,519.08$, and $639.12 \mathrm{~W} . \mathrm{m}^{-2}$ for the TfcCLT, TCN, TFCN, TAL, and AMB treatments, respectively. This index responded similarly to the BGHI. The RHL in the no-shade environment was high. These results show a tendency and/or values similar to those obtained by Silva et al. (2015, a, b) and Akamine \& Passini (2017).

The BGHI index is an important indicator of the environmental conditions; however, the thermal changes caused by the wind near the roofs and even inside the models should be avoided. Occurrence of such thermal changes may distort the results normally expected for the BGHI as compared to the RHL index, which considers the air velocity combined with other variables. According to Guimarães et al. (2014), animals kept in environments with a larger thermal amplitude may show a compromised performance because of having to adapt to the temperature variations in a short time.

Figure 6 shows the development of the $T_{b g}$ index as a function of the schedules. The $T_{b g}$ index behavior during the day was similar to those of the BGHI and RHL indices, verifying again that the CLT registered the lowest values in the environment with roof.

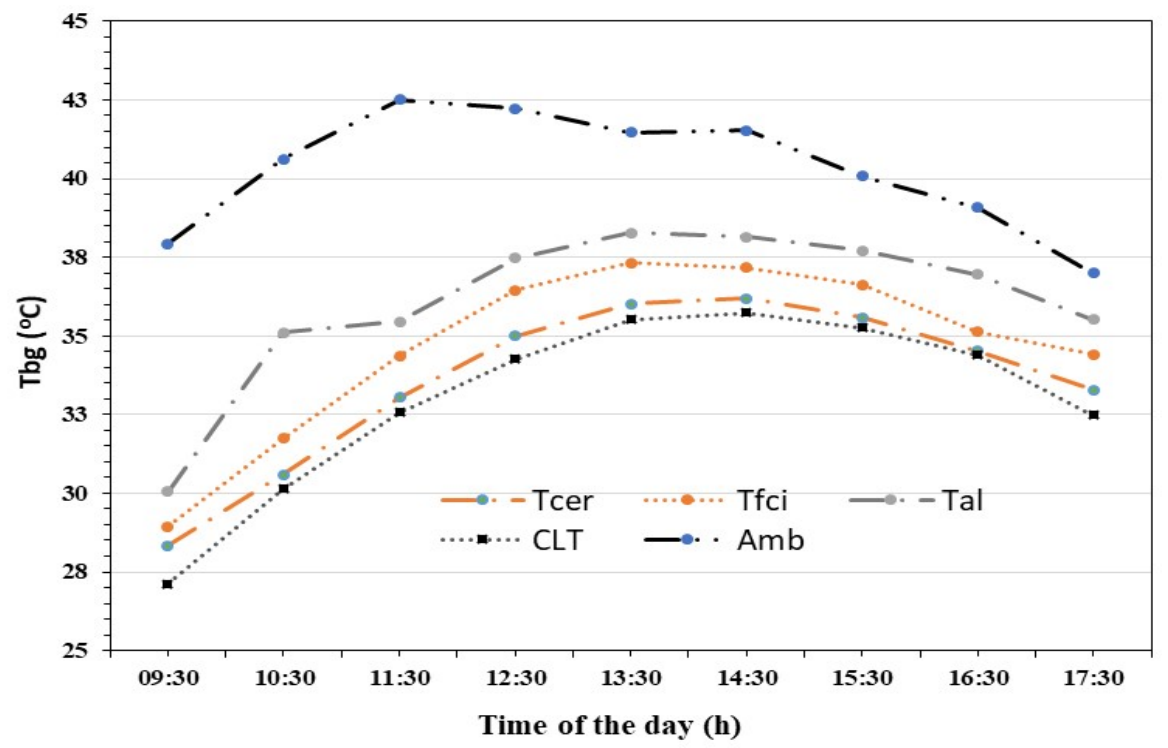

TfCCLT - corrugated fiber cement clean tiles mounted on the structural lining of the CLT formed by a self-supporting structure; TCN ceramic clean tiles; TFCN — corrugated fiber cement clean tiles; and TAL — corrugated aluminum clean tiles.

FIGURE 6. Average values of the $T_{b g}$ index for all treatments at different measurement times.

Figure 7 depicts the development of the specific enthalpy (h) as a function of the measurement times.

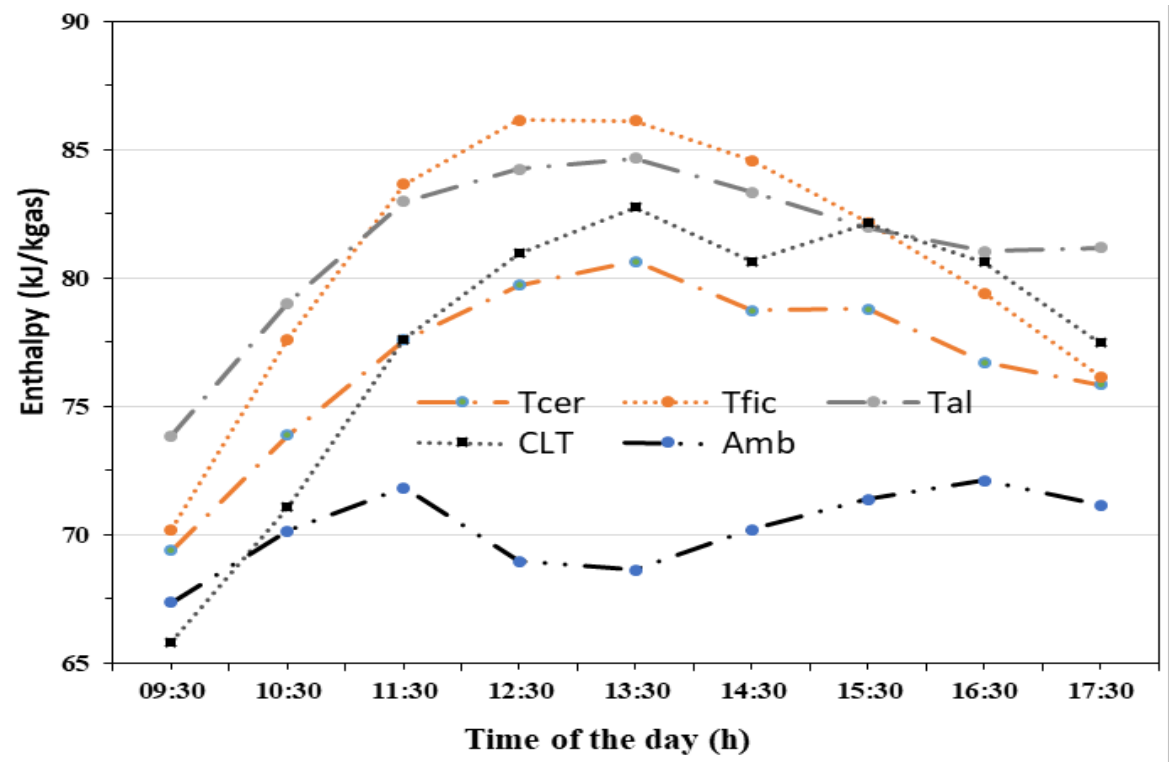

TfCCLT — corrugated fiber cement tiles mounted on the structural lining of the CLT formed by a self-supporting structure; TCN — ceramic tiles; TFCN — corrugated fiber cement tiles; and TAL — corrugated aluminum tiles.

FIGURE 7. Average values of enthalpy for all treatments at different measurement times. 
The external specific enthalpy $(\mathrm{H})$ of the air (Silva et al., 2015b) was calculated to determine the days with the highest "caloric content," which are considered as the days of greatest discomfort. The models were closed; hence, the specific enthalpy inside these environments was larger in comparison to the external enthalpy of the air. For this variable, the CLT roof presented a greater enthalpy in schedules of greater heat. This result is attributable to the self-supporting characteristic of this roof structure, which also works as a lining that stores heat. This advantage cannot be observed with the ceramic roof.

Compared to aluminum, the roof tiles with the same thermal performance presented a thermal effectiveness $(\varepsilon)$ equal to 1 . The roof tiles with a better performance showed values higher than 1 , whereas those with the worse performance had values lower than 1 . The highest values of effectiveness were found in the TCN (1.89), TFCN (1.44), and TfCCLT (2.01) treatments. These values are similar to those obtained by Silva et al. (2015, a, b), albeit with minor differences, because the discrepancy has several causes, such as type, thermal characteristic, and state of conservation of the tiles in question, external air circulation in the instruments located inside the models, and the characteristics of the local climate at that moment.

The discussions and comparisons in this study can be further developed if more specific publications in the literature related to the thermal comfort of the CLT for rural use are available.

\section{CONCLUSIONS}

In terms of thermal comfort, conventional roofs were ranked herein as follows from best to worst: ceramic, fiber cement, and aluminum. The reduced-scale model with a fiber cement roof associated with the CLT showed reduced indices of thermal comfort compared to the other conventional roofs. The CLT showed potential for use in rural buildings due to the thermal comfort it presented and its advantage of being self-supporting. However, challenges still remain, among which is the need for investments, new research, and further knowledge about this material and other aspects, particularly, the acceptance of this technological innovation in the rural environment. Moreover, all evaluated models did not provide the desirable thermal comfort throughout the day for intensively reared animals, requiring the use of environmental control systems aimed at optimal thermal indices inside the premises.

\section{ACKNOWLEDGMENTS}

The authors are grateful to the Santa Catarina Research Foundation (FAPESC) and the Santa Catarina State University (UDESC) in Brazil for their financial support on this research.

\section{REFERENCES}

Adekunle TO, Nikolopoulou M (2018) Post-occupancy evaluation on people's perception of comfort, adaptation and seasonal performance of sustainable housing: a case study of three prefabricated structural timber housing developments. Intelligent Buildings International (7):1-29. DOI: http://dx.doi.org/10.1080/17508975.2018.1493677
Akamine LA, Passini R (2017) Índices de conforto térmico para aves em modelos reduzidos com diferentes coberturas. Revista Espacios 38(6):7-21.

Carneiro TA, Guiselini C, Pandorfi H, Lopes Neto JP, Lopes V, Souza RFL (2015) Condicionamento térmico primário de instalações rurais por meio de diferentes tipos de cobertura. Engenharia Agrícola e Ambiental 19(11):1086-192.

Castro AC, Silva IJO, Nazareno AC, Nunes MLA, Piedade SMS (2017) Thermal efficiency of different coverage materials in reduced models of animal husbandry facilities: a case study. Engenharia Agrícola 37(3):403-413. DOI: http://dx.doi.org/10.1590/1809-4430-

Eng.Agric.v37n3p403-413/2017

Dalcin VC, Fischer V, Daltro DS, Alfonzo EPM, Stumpf MT, Kolling GJ, Silva MVGB, Mcmanus C (2016) Physiological parameters for thermal stress in dairy cattle. Revista Brasileira de Zootecnia 45(8):21-29.

Farias R, Pereira MF, Costa AS, Castro EKF, Souza MNB, Santos NC, Santos GC (2017) Avaliação da temperatura do telhado de diferentes materiais de cobertura para construção do telhado de aviários móveis.

Agroecossistemas 9(2):308-315.

Guimarães MCC, Furtado DA, Nascimento JWB, Tota LCA, Silva CM, Lopes KBP (2014) Efeito da estação do ano sobre o desempenho produtivo de codornas no semiárido paraibano. Engenharia Agrícola e Ambiental 18(2):231-237.

Jentzsch R, Baêta FC, Tinôco IFF, Damasceno FA, Saraz JAO (2013) Parâmetros arquitetônico-ambientais para construção e testes em modelos reduzidos, representativos de galpões avícolas com base em similitude. Engenharia da Agricultura 21(1):19-30.

Kollár M, Štefko J (2016) Control of the indoor climate in summer using the thermophysical properties of wood materials in terms of transient thermal state. Key Engineering Materials (688):167-174. DOI: http://dx.doi.org/10.4028/www.scientific.net/KEM.688.167

Leiva CB, Soto PG, Pulgar EP, Cascante DV (2018) CLT Building's thermal behavior simulation using design builder software. In: World Conference on Timber Engineering. Seoul, Proceedings...

Marchezan WM, Seeger MG, Picetti TS, Fialho SS (2014) Estresse térmico em bovinos leiteiros. Revista CFMV 20(63):49-54.

Melo T, Furlan R, Milani A, Buzanskas M, Moura A, Mota D, Cardoso D (2013) Avaliação de diferentes inclinações e exposições de telhado em três tipos de cobertura em modelos reduzidos de instalações zootécnicas. Semina 34(3):1327-1338. 
Neto MM, Nääs IA (2014) Software de agricultura de precisão para monitorar aspectos ambientais de conforto térmico na bovinocultura de leite. Brazilian Journal of Biosystems Engineering 8(2):112-127.

Pérez G, Vila A, Solé C, Coma J, Castell A, Cobeza LF (2015) The thermal behavior of extensive green roofs under low plant coverage conditions. Energy Efficiency 8:881-894.

Rosselle L, Permentier L, Verbeke G, Driessen BR, Geers, $R$ (2014) Interactions between climatological variables and sheltering behavior of pastoral beef cattle during sunny weather in a temperate climate. Journal of Animal Science 91:943-949.

Sampaio CAP, Terezo RF, Rosa TO, Burigo MC, Andrade LB (2018) Similitude e desempenho térmico em telhados não convencionais. Engenharia Agrícola 38(1):1125-1134.
Silva MG, Martin S, Oliveira CEG, Moscon ES,

Damasceno FA (2015a) Desempenho térmico de tipos de coberturas no interior de modelos reduzidos de galpões avícolas. Energia na Agricultura 30(3):269-275.

Silva KCP, Campos AT, Yanagi Junior T, Cecchin D, Lourençoni D, Ferreira JC (2015b) Reaproveitamento de resíduos de embalagens Tetra Pak- $₫$ em coberturas. Engenharia Agrícola e Ambiental 19(1):58-63. DOI: http://dx.doi.org/10.1590/1807-1929/agriambi.v19n1p58$63 / 2015$

Souza IJ, Oliveira ZB, Saretta E, Rodrigues LR, Silva CM, Tondolo T (2018) Análise do conforto térmico em modelos reduzidos de galpões agrícola. Ciência e Natura 40:140-147. DOI:

http://dx.doi.org/10.5902/2179460X35512/2018 